\title{
Diagnostic Values of P-Wave Dispersion to Detect Diastolic Function in Patient with Hypertension
}

\author{
Braghmandaru Adhi Bhaskara*, Rano Irmawan, Lucia Kris Dinarti, Hasanah Mumpuni \\ Department of Cardiology and Vascular Medicine \\ Faculty of Medicine Universitas Gadjah Mada - Dr. Sardjito Hospital, Yogyakarta, Indonesia
}

\author{
Corresponding author : \\ Braghmandaru Adhi Bhaskara, MD, - email: dr.braghmandaru.bhaskara@gmail.com \\ Department Cardiology and Vascular Medicine, Faculty of Medicine Universitas Gadjah Mada - Dr. Sardjito Hospital, \\ Yogyakarta, Indonesia, Jalan Farmako Sekip Utara, Yogyakarta 55281
}

Manuscript submitted: June 21, 2017; Revised and accepted: January 11, 2018

\begin{abstract}
Background: Hypertension is one of the main causes of cardiovascular disease. Patients with hypertension have increase risk of heart failure compared to populations with normal blood pressure. Clinical evidence shows diastolic dysfunction (DD) can lead to heart failure. Diagnostic of DD with echocardiography is important but access to echocardiography machines is limited compared to electrocardiography (ECG). ECG research correlates P-wave dispersion (PWD) with DD. The aim of this study is to determine the value of PWD to diagnose DD in patients with hypertension.

Methods: A cross sectional study was conducted in patients with hypertension at Dr. Sardjito Hospital. Patients received echocardiography, ECG, blood pressure measurement and data recording. The diastolic dysfunction was determined based on 2016 ASE/EACVI criteria. We conducted ROC analysis to determine the cut-off point of P-wave dispersion and the area under the curve (AUC) value, and bivariate analysis on demographic and clinical factors related to PWD. Multivariate analysis was performed to determine the independent factors affecting PWD. Results: 113 patients met the criteria of the study subjects, with 47 men $(37.2 \%)$, mean age $58.32 \pm 11.17$ years. Thirteen $(11.5 \%)$ subjects had DD and 37 subjects $(32.7 \%)$ with increased PWD. Results showed increased PWD above 71.4 m.s with AUC $76.2 \%$, sensitivity $75 \%$, specificity $72.2 \%$, positive predictive value $33.3 \%$, negative predictive value $96 \%$, and accuracy of $72.5 \%$ in diagnosing DD.

Conclusion: This is the first study to examine the diagnostic value of PWD to detect diastolic function based on 2016 ASE/EACVI criteria. We found PWD above cut-off point $71.4 \mathrm{~m} . \mathrm{s}$ has a moderate diagnostic value for detecting $\mathrm{DD}$ in patients with hypertension.
\end{abstract}

Keywords: Hypertension, diastolic dysfunction, P-wave dispersion.

\section{INTISARI}

Latar Belakang: Hipertensi merupakan salah satu penyebab utama penyakit kardiovaskular. Risiko gagal jantung pada pasien hipertensi meningkat dibandingkan populasi normal. Disfungsi diastolik dapat menimbulkan gejala gagal jantung. Penegakan diagnosis disfungsi diastolik dengan ekokardiografi sangat penting namun akses pelayanan ekokardiografi terbatas dibandingkan akses terhadap EKG. Dispersi gelombang P diketahui berhubungan dengan disfungsi diastolik. Penelitian ini bertujuan untuk mengetahui nilai diagnostic dispersi gelombang $\mathrm{P}$ terhadap disfungsi siastolik pada pasien hipertensi.

Metode Penelitian: Studi potong lintang ini dilakukan terhadap pasien dengan hipertensi yang dilakukan periksaan ekokardiografi di RSUP Dr. Sardjito. Setelah dilakukan ekokardiografi pasien kemudian dilakukan perekaman EKG dan pengukuran tekanan darah serta pencatatan data. Disfungsi diastolik ditentukan dengan kriteria ASE/EACVI tahun 2016. Analisis ROC dilakukan untuk menentukan cut-off point pemanjangan dispersi gelombang $\mathrm{P}$ dan melihat nilai AUC. Analisis bivariat dilakukan terhadap faktor demografi dan klinis yang berhubungan dengan 
dispersi gelombang $\mathrm{P}$, dilanjutkan analisis multivariat untuk mengetahui faktor independen yang mempengaruhi dispersi gelombang $P$.

Hasil: Terdapat 113 pasien yang memenuhi kriteria subyek penelitian, $47(37,2 \%)$ laki-laki dengan rerata usia $58,32 \pm 11,17$ tahun, $13(11,5 \%)$ subyek memiliki disfungsi diastolik dan 37 subyek $(32,7 \%)$ dengan pemanjangan dispersi gelombang P. Penelitian ini mendapatkan pemanjangan dispersi gelombang $\mathrm{P}$ di atas cut-off point 71,4 mili detik memiliki nilai AUC $76,2 \%$ sensitivitas $75 \%$, spesifisitas $72,2 \%$, nilai duga positif $33,3 \%$, nilai duga negatif $96 \%$, dan akurasi $72,5 \%$ dalam mendiagnosis disfungsi diastolik.

Simpulan: Studi ini adalah yang pertama meneliti nilai diagnostik dispersi gelombang $P$ terhadap fungsi diastolik berdasarkan kriteria ASE/EACVI 2016. Kami menemukan pemanjangan dispersi gelombang $\mathrm{P}$ diatas 71,4 mili detik memiliki nilai diagnostik sedang untuk mendeteksi disfungsi diastolik pada pasien hipertensi.

\section{INTRODUCTION}

Hypertension is one of the leading cause of cardiovascular disease. Study in Malaysia showed that the prevalence of hypertension reached $24 \%$ and is a major cause of heart failure with high mortality. ${ }^{1}$ Hypertension causes thickening of the ventricular wall as compensation for increased pressure on the ventricular wall which ultimately results in concentric hypertrophy of the left ventricle and causes diastolic dysfunction. ${ }^{2}$ In the left ventricular diastolic dysfunction condition, there will be an increase in end diastolic pressure and increase of the dimension of the left atrium. The increased left atrial pressure and dimension increase the risk of atrial fibrillation, which in turn will increase diastolic dysfunction severity and worsening of symptoms of heart failure ${ }^{3}$.

Diagnosing diastolic dysfunction with echocardiography is important because of the large number of morbidities that can result from poorly handled diastolic dysfunction, but access to echocardiography machines is limited. Electrocardiography machines are commonly found in health care providers. We examined ECG parameters, which could provide diagnostic indicators to diastolic dysfunction (DD). The ECG examination correlates $P$-wave dispersion (PWD) with DD. In this study, PWD was obtained by substracting the shortest duration of the $\mathrm{P}$-wave from the longest $\mathrm{P}$-wave duration in various ECG leads. One recent study found that $\mathrm{P}$-wave parameters correspond to left atrial volume index (LAVI) and left ventricular diastolic dysfunction. ${ }^{4}$

We conducted this study in order to examine the diagnostic value of $P$-wave dispersion in predicting the occurence of DD in patients with hypertension.

\section{METHOD}

An analytic observational study using cross sectional design was conducted in RSUP Dr. Sardjito Hospital, Yogyakarta, Indonesia from March to April 2017. Echocardiography and ECG data were examined on the same day starting from the issuance of ethical clearance until the research sample was fulfilled. Target populations were patients with hypertension who underwent echocardiography as an outpatient. Inclusion criteria included: male or female aged $18-75$ years old with diagnosis of hypertension with normal cardiac systolic function, and normokinetics determined by echocardiography, and willing to complete this research. Exclusion criteria included: patients with congenital heart disease, primary valve disease, permanent pacemakers, $P$-wave dispersion cannot be calculated due to unidentifiedP-wave, atrial fibrillation, artifacts, and/or indeterminate diastolic function based on ASE/EACVI 2016 recomendation. The required sample size was determined to be 81 subjects.

Demographic and clinical data include: age, sex, pulse rate, systolic and diastolic blood pressure, diabetes mellitus, smoking 
history, ischemic heart disease, use of ACE inhibitors, angiotensin II receptor blockers (ARB), calcium channel blockers, beta blockers, thiazide diuretics, and echocardiographic criteria recorded in the Case Report Form.

\section{ECG examination}

A 12 lead EGG recording was done in patients with supine position, paper speed of $50 \mathrm{~mm} / \mathrm{sec}$ and amplitude of $20 \mathrm{~mm} / \mathrm{mV}$ using General Electric (GE) Mac i ECG machine. The ECG recording was then embedded in a sequence on paper and then scanned using a HP Deskjet $2520 \mathrm{HC}$ scanner with a resolution of 300 dot per inch (DPI) and stored in Joint Photographic Experts Group (JPG) format and then analysed using the ImageJ software on a high resolution computer screen. The value of $\mathrm{P}$-wave dispersion is obtained by substracting the longest duration of the $\mathrm{P}$-wave and the shortest $P$-wave recorded in twelve leads in a single ECG recording. The P-wave measurement starts from the beginning of the positive deflection until back to the isoelectric line. ${ }^{5}$

\section{Echocardiography examination}

Echocardiographic examination was performed using the echocardiography machine GE Vivid 7 Pro (GE Vingmed Ultrasound AS, Horten, Norway) and GE Vivid S6 N (GE Vingmed Ultrasound AS, Horten, Norway) in echocardiography division in Dr. Sardjito General Hospital Yogyakarta. The diastolic dysfunction diagnosis used in this study is based on the American Society of Echocardiography 2016 recommendations. ${ }^{6}$

\section{Statistical analysis}

Statistical analysis was performed with $\mathrm{IBM}^{\circledR}$ SPSS ${ }^{\circledR}$ version 22 for Windows. The numerical variables are presented in the form of the mean $\pm S D$ (standard deviation) and categorical variables will be presented as a percentage. Categorical variables testing are compared with $2 \times 2$ tables using Chi Squared $\left(x^{2}\right)$ or Fisher Exact Tests. The cut-off point of $\mathrm{P}$-wave dispersion was determined using the sensitivity-specificity graph from the receiver operator characteristics (ROC) curve. Numerical data are compared by using unpaired Student $t$-test or Mann Whitney $U$ test based on the normality of data distribution. Confounding variables were analyzed using bivariate analysis followed by multivariate analysis. If there was a variable with a value of $p<0.25$ in the bivariate test, it was included in the multivariate analysis. The $p$ value $<0.05$ was considered statistically significant. The assessment of the consistency of ECG readings and the measurement of diastolic function by echocardiography was performed with Kappa, if the coefficient of Kappa $>0.8$ with $p<0.05$ measurement was considered similar. Sensitivity, specificity, positive and negative predictive values were assessed using $2 \times 2$ tables.

\section{Ethical Consideration}

This study was ethicaly approved by the ethical committee of medical research Faculty of Medicine,Universitas Gadjah Mada, Yogyakarta and permission from the Dr. Sardjito General Hospital Yogyakarta, Indonesia.

\section{RESULTS}

This research was conducted from March to April 2017 in Dr. Sardjito Hospital. There were 270 subjects with a history of hypertension. The total subjects met the inclusion criteria were 113 subjects.

The subjects consisted of 42 men (37\%) and 71 women $(63 \%)$. The mean age of the subjects was $58.29 \pm 11.21$ years with median systolic blood pressure $140 \mathrm{mmHg}$, while diastolic blood pressure with median $80 \mathrm{mmHg}$. Seven subjects $(6.1 \%)$ had ECG recording indicating ischemic heart disease and 13 subjects $(11.5 \%)$ had diabetes. Fifty-three subjects (47\%) received one or more antihypertensive medications, with 
Table1.Baseline characteristics of the study subjects

\begin{tabular}{lc}
\hline \multicolumn{1}{c}{ Variables } & Frequency \\
\hline Male sex, $\mathrm{n}(\%)$ & $42(37.2 \%)$ \\
Age \pm SD (years old)* & $58.32 \pm 11.17$ \\
Blood pressure $(\mathrm{mmHg})$ & \\
$\quad$ Systolic** & \\
Diastolic $^{* *}$ & $140(100-200)$ \\
Pulse (bpm) & $80(50-110)$ \\
Diabetes Melitus, $\mathrm{n}(\%)$ & $77(47-100)$ \\
Ischemic Heart Disease, $\mathrm{n}(\%)$ & $13(11.5 \%)$ \\
Active smoker, $\mathrm{n}(\%)$ & $7(6.2 \%)$ \\
ACE inhibitor, $\mathrm{n}(\%)$ & $15(13.3 \%)$ \\
AR blocker, $\mathrm{n}(\%)$ & $11(9.7 \%)$ \\
Beta blocker, $\mathrm{n}(\%)$ & $27(23.9 \%)$ \\
CCB, $\mathrm{n}(\%)$ & $17(15 \%)$ \\
\end{tabular}

Note: $A C E=$ Angiotensin Converting Enzyme, $\mathrm{AR}=$ Angiotensin II Receptor, $\mathrm{CCB}=$ Calcium Channel Blocker

*normal data distribution, presented in mean \pm s.d, analysed using independent sample t-test

**abnormal data distribution, presented in median (minimum-maximum value) analysed using MannWhitney Test

most subjects using calcium group blockers 29 subjects $(25.6 \%)$, followed by ARB 27 subjects (23.9\%) and ACE inhibitor 11 subjects (9.7\%).

The ROC curve analysis showed AUC value $76.2 \%$ ( $p=0.003 ; 95 \% \mathrm{Cl} 0.620 \%-0.920 \%)$ at $\mathrm{P}$-wave dispersion cut-off point $\geq 71.4 \mathrm{~ms}$ with sensitivity $75 \%$ and spesificity $72.3 \%$. Area under the curve (AUC) are in the area $70-80 \%$ so that the strength of diagnostic test in this study is moderate. $^{7}$ When we continued to analyze the P-wave dispersion with cut-off point $71.4 \mathrm{~ms}$ using $2 \times 2$ table then we found sensitivity $75 \%$, specificity $72.2 \%$, positive predictive value $33.3 \%$, negative predictive value $96 \%$, and accuracy of $72 \%$.

Several confounding variables which have been known to affect $\mathrm{P}$-wave dispersion and diastolic dysfunction include: age, gender, diabetes, smoking, ischemic heart disease, use of beta-blocker drugs, calcium channel blockers, AR blockers, ACE inhibitors, and thiazide diuretics. Therefore, it was necessary to use

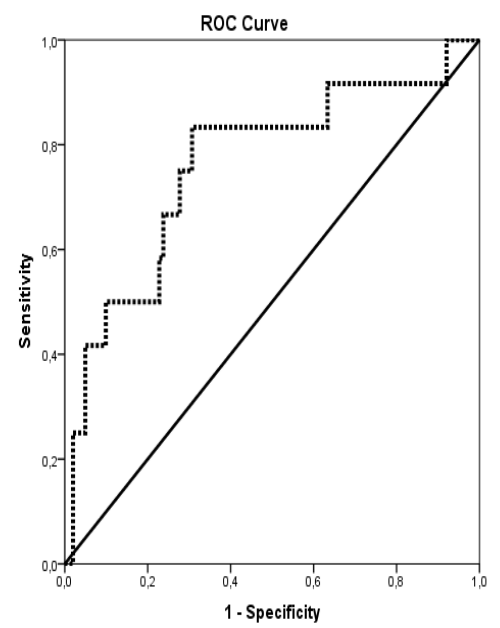

Figure1. Receiver Operating Curve (ROC) of diagnostic values of $\mathrm{P}$-wave dispersion to detect diastolic function in patients with hypertension

bivariate testing to find the correlation of these factors to $P$-wave dispersion. Factors that have $p>0.25$ on the bivariate test were analysed using multivariate test to determine if these factors independently correlated with $\mathrm{P}$-wave dispersion and the result was considered significant if it has $p<0.05$.

Bivariate analysis was performed on each confounding factor of P-wave dispersion (Table 2). There were significant differences between groups of subjects with ischemic heart disease and those who received therapy of ARB $(p<0.05)$, while subjects with diastolic blood pressure $\geq 90$ $\mathrm{mmHg}$, who had a history of smoking, and had beta-blocker therapy reached a value of $p<0.25$, so further analysis was required with multivariate analysis.

Based on the results of the multivariate analysis, it can be concluded that the use of ARB is an independent variable that affects the P-wave dispersion in this study with $p$ value $<0.05$.

\section{DISCUSSION}

Our study involved 113 subjects with the majority of subjects being female $(62.8 \%)$ with an average age of $58.32 \pm 11.17$ years. 


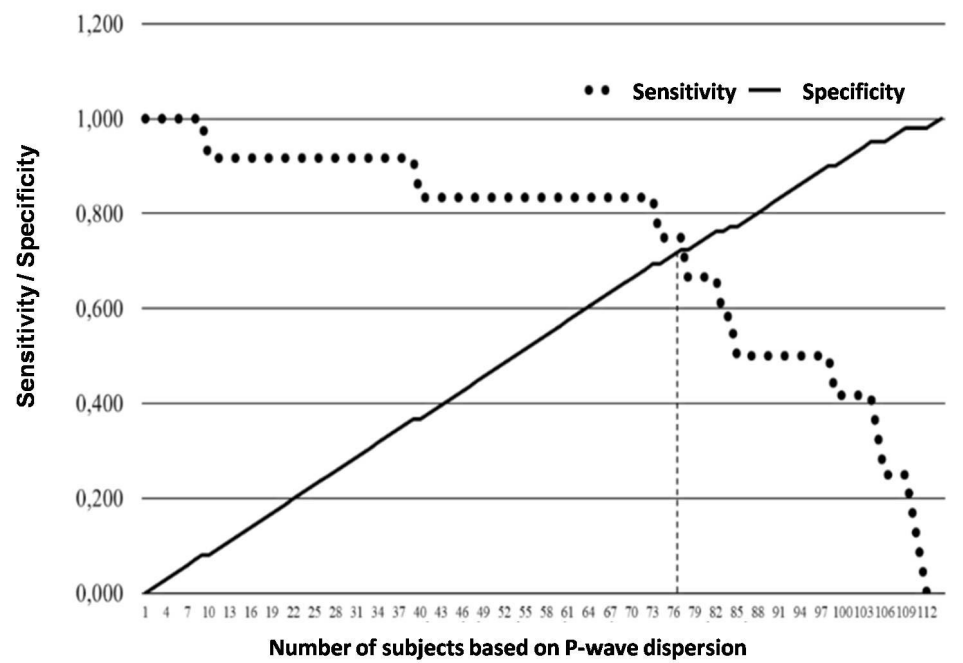

Figure 2. Sensitivity-specificity graph to define optimal cut-off point of P-wave dispersion to detect diastolic function in patients with hypertension

Table 2. Bivariate analysis of clinical characteristic and P-wave dispersion

\begin{tabular}{|c|c|c|c|c|c|}
\hline \multirow{2}{*}{ Variable } & \multicolumn{2}{|c|}{ P-wave dispersion } & \multirow{2}{*}{ OR } & \multirow{2}{*}{$95 \% \mathrm{Cl}$} & \multirow{2}{*}{$p$} \\
\hline & $\geq 71.4 \mathrm{~ms}(\mathrm{n}=37)$ & $<71.4 \mathrm{~ms}(\mathrm{n}=76)$ & & & \\
\hline \multicolumn{6}{|l|}{ Sex } \\
\hline Male & $15(40 \%)$ & $27(36 \%)$ & 1.237 & $0.552-2.773$ & 0.605 \\
\hline \multicolumn{6}{|l|}{ Age (years old) } \\
\hline$\geq 58$ & $19(51 \%)$ & $41(54 \%)$ & 0.901 & $0.410-1.979$ & 0.795 \\
\hline \multicolumn{6}{|l|}{ Systolic BP (mmHg) } \\
\hline$\geq 140$ & $27(73 \%)$ & $55(72 \%)$ & 1.031 & $0.426-2.492$ & 0.946 \\
\hline \multicolumn{6}{|l|}{ Diastolic BP (mmHg) } \\
\hline$\geq 90$ & $15(40 \%)$ & $21(28 \%)$ & 1.786 & $0.781-4.082$ & $0.167^{*}$ \\
\hline \multicolumn{6}{|l|}{ Pulse (bpm) } \\
\hline$\geq 76$ & $20(55 \%)$ & $37(49 \%)$ & 1.24 & $0.564-2.726$ & 0.592 \\
\hline Diabetes Melitus & $6(16 \%)$ & $7(9 \%)$ & 1.908 & $0.592-6.146$ & 0.273 \\
\hline Active smoker & $29(78 \%)$ & $69(91 \%)$ & 2.719 & 0.902-8.195 & $0.068^{*}$ \\
\hline Ischemic Heart Disease & $5(12 \%)$ & $2(3 \%)$ & 5.781 & $1.065-31.377$ & $0.037^{* *}$ \\
\hline ACE inhibitor & $4(11 \%)$ & $7(9 \%)$ & 1.195 & $0.327-4.369$ & 0.748 \\
\hline AR blocker & $15(40 \%)$ & $12(16 \%)$ & 3.636 & $1.478-8.948$ & $0.004^{* *}$ \\
\hline Beta blocker & $8(22 \%)$ & $9(9 \%)$ & 2.054 & $0.721-5.853$ & $0.172^{*}$ \\
\hline CCB & $9(24 \%)$ & $20(26 \%)$ & 0.9 & $0.363-2.232$ & 0.82 \\
\hline
\end{tabular}

Note: $\mathrm{ACE}=$ Angiotensin Converting Enzyme, $\mathrm{AR}=$ Angiotensin II Receptor, $\mathrm{CCB}=\mathrm{Calcium}$ Channel Blocker, $\mathrm{BP}=$ Blood preesure, ${ }^{*} \mathrm{p}<0.25,{ }^{* *} \mathrm{p}<0.05$. 
Table 3. Comparison of echocardiographic parameter with P-wave dispersion

\begin{tabular}{|c|c|c|c|}
\hline \multirow{2}{*}{ Echocardiographic parameters } & \multicolumn{2}{|c|}{ P-wave dispersion } & \multirow{2}{*}{$\mathrm{p}$} \\
\hline & $\geq 71.4 \mathrm{~m} \mathrm{~s}(\mathrm{n}=37)$ & $<71.4 \mathrm{~m} \mathrm{~s}(\mathrm{n}=76)$ & \\
\hline LVIDd $(\mathrm{mm})^{*}$ & $46.35 \pm 5.79$ & $44.46 \pm 4.28$ & 0.054 \\
\hline LVPWDd $(\mathrm{mm})^{* *}$ & $10(6-16)$ & $9(6-14)$ & 0.228 \\
\hline IVSDd $(\mathrm{mm})^{\star *}$ & $11(7-16)$ & $10(6-17)$ & 0.133 \\
\hline LAVI** & $22(10-60)$ & $21(11-44)$ & 0.534 \\
\hline e' septal velocity $(\mathrm{cm} / \mathrm{s})^{\star *}$ & $7(3-13)$ & $9(5-17)$ & 0.001 \\
\hline$e^{\prime}$ lateral velocity $(\mathrm{cm} / \mathrm{s})^{\star *}$ & $9(4-15)$ & $11(6-29)$ & 0.001 \\
\hline E/e' ratio** & $7.57(0-26.73)$ & $7.22(0.9-17)$ & 0.028 \\
\hline TR maximum velocity $(\mathrm{m} / \mathrm{s})^{* *}$ & $0(0-144)$ & $0(0-29)$ & 0.5 \\
\hline deceleration Time $(\mathrm{dT})^{* *}$ & $198(0-466)$ & $198(98-434)$ & 0.497 \\
\hline LV Mass** & $162.1(78.3-358.9)$ & $138.7(59.91-334.24)$ & 0.065 \\
\hline
\end{tabular}

Note: LVIDd=Left ventricular internal diameter end diastole, LVPWd=Left ventricular posterior wall end diastole,IVSd=Interventricular septal end diastole,LAVI=Left Atrial Volume Index, LV=Left Ventricle, TR= Tricuspid Regurgitation.

${ }^{*}$ normal data distribution, presented in mean \pm s.d , analysed using independent sample t-test

**abnormal data distribution, presented in median (minimum-maximum value) analysed using Mann-Whitney Test

Table 4. Multivariate analysis of factors which affect P-wave dispersion

\begin{tabular}{lccccc}
\hline \multicolumn{1}{c}{ Variable } & \multicolumn{2}{c}{$\mathrm{P}$-wave disperion } & \multirow{2}{*}{ OR } & \multirow{2}{*}{$95 \% \mathrm{Cl}$} & \multirow{2}{*}{$\mathrm{P}$} \\
\hline Diastolic BP & $\geq 71.4 \mathrm{~ms}(\mathrm{n}=37)$ & $<71.4 \mathrm{~ms}(\mathrm{n}=76)$ & & & \\
Ischemic Heart Disease & $15(40 \%)$ & $21(28 \%)$ & 0.406 & $0.163-1.009$ & 0.052 \\
Active smoker & $5(12 \%)$ & $2(3 \%)$ & 0.226 & $0.037-1.366$ & 0.105 \\
AR blocker & $29(78 \%)$ & $69(91 \%)$ & 2.454 & $0.733-8.219$ & 0.145 \\
Beta blockers & $15(40 \%)$ & $12(16 \%)$ & 0.250 & $0.094-0.664$ & $0.005^{*}$ \\
\hline
\end{tabular}

Note: $A R=$ Angiotensin II Receptor , BP=Blood preesure, ${ }^{*} p<0.05$

P-wave dispersion data in this study has normal distribution with mean value $63.94 \pm 19.51 \mathrm{~ms}$, then from calculation with ROC curve, we found the cut-off point of P-wave dispersion 71.4 m.s. The diagnostic values obtained using the cut-off point were $75 \%$ sensitivity, $72.2 \%$ specificity, $33.3 \%$ positive predictive value, and a negative predictive value of $96 \%$. This result is different compared to the diagnostic value of P-wave dispersion based on a study by Taha et al. (2015) which obtained a $98 \%$ sensitivity and $64 \%$ specificity with a $45 \mathrm{~m}$.s cut off point based on the ROC curve. ${ }^{8}$

The differences of these results may be due to differences in characteristics of the study subjects, diagnostic criteria for diastolic dysfunction, and ECG reading methods. Subjects in our study were all patients with hypertensive and there was a significant difference in the proportion of subjects with diastolic dysfunction compared to the total number of study subjects. In the study by Taha et al. (2015) the study subjects were the patients who were planned to do the stress ECG test with the inclusion criteria of patients with negative stress test,and a history of hypertension was only found in $38.5 \%$ of all subjects. The diastolic dysfunction criteria in this study was to use the ratio parameter E/e' where the value of $\geq 15$ was classified as diastolic dysfunction, with $60 \%$ of subjects having 
diastolic dysfunction. The ECG was read using a magnifying glass to obtain $\mathrm{P}$-wave dispersion with characteristics: mean $47 \pm 10$ ms in subjects with normal diastolic function and $69 \pm 10 \mathrm{~ms}$ in subjects with diastolic dysfunction. A study from Dilaveris et al. (1999) comparing various $\mathrm{P}$-wave measurement methods to obtain $\mathrm{P}$-wave duration, found that measurements are more stable and reliable by using high resolution digital screens compared to reading using ECG paper using magnifying glass and calipers. ${ }^{9}$

The AUC value of this research is $76.2 \%$ in the range of $70-80 \%$ so that the strength of the diagnostic test in this study is moderate. Another approach is clinical, which is compared to the AUC value of the existing diagnostic methods. The study of Tsai et al. (2013) about the correlation of $\mathrm{P}$-wave dispersion with LAVI and diastolic dysfunction shows an increase in P-wave dispersion above $65 \mathrm{~m} . \mathrm{s}$ has a $61.7 \%$ AUC with a sensitivity of $61.8 \%$ and a specificity of 56.95 in detecting diastolic dysfunction. ${ }^{4}$ Another study by Srivastava et al. (2005) on the role of echocardiographic doppler in the assessment of diastolic dysfunction showed the $A U C$ values for each of the E 'lateral, E' medial, E / e 'velocity parameters were $77 \%, 80 \%$, and $79 \% .{ }^{10}$

Gunduz et al. (2005) studied the relationship of P-wave dispersion with diastolic dysfunction and compared with the normal population, with $54 \%$ of subjects suffering from hypertension with diastolic dysfunction were divided into 3 classes in this study, and it was found that $P$-wave dispersion increased significantly in patients with diastolic dysfunction (53 \pm 9 m.s vs. $43 \pm 9$; $p<0.01$ ), but the difference of $\mathrm{P}$-wave dispersion between the 3 classes of diastolic dysfunction was not significantly different ( $p>0.05) .{ }^{11}$ Another study compared $P$-wave dispersion in hypertensive patients with and without a paroxysmal AF history found that $\mathrm{P}$-wave dispersion $>44 \mathrm{~m}$.s can distinguish hypertensive patients with and without paroxysmal atrial fibrillation with $77 \%$ sensitivity and $62 \%$ specificity. ${ }^{12}$ Research to diagnose diastolic dysfunction by using $\mathrm{P}$-wave dispersion with all subjects who were hypertension patients has never been done beforeusing the ASE/ EACVI 2016 recommendations. To the author best knowledge, this research is the first to apply the new guidelines to use $\mathrm{P}$-wave dispersion to diagnose diastolic dysfunction.

Ischemic heart disease has been known to influence P-wave dispersion based on Dilaveris et al. (2001) studies in patients with stable angina. ${ }^{13}$ Another study found no significant differences between the two groups. ${ }^{11}$ This result is similar to our study that had significant ischemic heart disease on $\mathrm{P}$-wave dispersion in bivariate tests but not significant after multivariate tests. This result is probably due to our exclusion of patients with decreased fraction ejection where most of the causes are ischemic heart disease.

Gender and age did not show statistically significant differences, this result is different from the study of Barutcu et al.(2009) which stated that $\mathrm{P}$-wave dispersion will increase with age,$^{14}$ but according toa study from Dagli et al. (2008) there were no significant differencesof $\mathrm{P}$-wave dispersion in terms of age and sex in hypertensive patients compared with normal patients. ${ }^{15}$ In our study systolic and diastolic blood pressure variables also did not differ significantly ( $p=0.946$ and 0.052 ) respectively.

The use of CCB medication was not significantly correlated to P-wave dispersion. The subjects in our study mostly used CCB medication in the form of amlodipine. The results of this study are consistent with previous studies by Fogari et al. (2008) which suggest that the use of amlodipine does not significantly reduce $\mathrm{P}$-wave dispersion compared with patients receiving both valsartan and ramipril therapy. ${ }^{16}$

Subjects in our study used ARB in the form of telmisartan, irbesartan, valsartan, 
and candesartan. The use of ARB remained significantly correlated with $\mathrm{P}$-wave dispersion after a multivariate analysis was performed with $p=0.005$; OR 0.25 (95\% Cl 0.094-0.664). The use of ARB also has a significant correlation with diastolic dysfunction with a $p$ value of 0.02 , OR 0.215 (95\% Cl 0.059-0.78). This result show the use of $A R B$ to be a confounding factor in this study.

The use of ARB has the effect of reducing the risk of diastolic dysfunction, as showed by Cuocolo et al. (1999) that patients whose received valsartan administration tend to have improved LV filling and better diastolic function. ${ }^{17}$ This study found that ACE inhibitor use was not significantly correlatedwith P-wave dispersion ( $p$ 0.788; OR 1.195 95\%; Cl: 0.327-4.369). This difference may be due to the small number of subjects using ACE inhibitors, i.e. 11 subjects $(9.7 \%)$ of a total of 113 subjects when compared to the proportion of subjects in the previous study. ${ }^{18,19}$ Previous studies with subjects of hypertensive patients and history of atrial fibrillation showed that valsartan and ramipril had a similar effect of decreasing blood pressure compared to amlodipine, but valsartan had a better reduction in $\mathrm{P}$-wave dispersion compared to ramipril while amlodipine did not decrease $\mathrm{P}$-wave dispersion. The mechanisms underlying the effects of $\mathrm{P}$-wave dispersion reduction are not known for certain, butARB and ACE inhibitors are considered to have antiarrhythmic effects through various pathways such as inhibiting ion channel function, angiotensin II induced angiotensic fibrosis, reducing atrial strain, improving left ventricular hemodynamic, and modulation of sympathetic nerve activation. ${ }^{16,20,21}$ Our study found that betablocker drugs did not affect P-wave dispersion, which is different from previous studies. ${ }^{19,22,23}$ This finding can be due to differences in the proportion of patients using beta blockers and the type of beta blockers used. The subjects of this study mostly used bisoprolol where the effect of bisoprolol on $P$-wave dispersion has not been studied previously.

\section{LIMITATIONS}

Several limitations should be considered in interpreting our results. The proportion of subjects with diastolic dysfunction is small when compared to the total number of subjects, so the result may not be able to accurately describe the condition in the general population. Since research subjects continued to receive antihypertensive therapy, the variety of medication used and their effect on P-wave dispersion could not be completely eliminated as confounding variables.

\section{CONCLUSION}

This research is the first study to investigate the diagnostic value of $\mathrm{P}$-wave dispersion to detect diastolic function using ASE/EACVI 2016 recommendations. Our findings demonstrate that P-wave dispersion above cut-off point $71.4 \mathrm{~m} . \mathrm{s}$ has moderate diagnostic value to detect diastolic dysfunction.

\section{ACKNOWLEDGEMENT}

Authors are grateful to all the members of Echocardiography Division in Dr. Sardjito Hospital for their assistance on this study.

\section{REFERENCES}

1. Mohamed A.L., Yong J., Masiyati J., Lim L., Tee S.C. 2004. The prevalence of diastolic dysfunction in patients with hypertension referred for echocardiographic assessment of left ventricular function. Malays J Med Sci, 11:66-74.

2. Lalande S., Johnson B.D. 2009. Diastolic dysfunction: a link between hypertension and heart failure. Drugs Today (Barc), 44:503-513.

3. Tushar A.Z., Majumder A.A.S, Azam S.T.M.A., Ullah M., Ahmed R. 2015. Relationship between $\mathrm{P}$ wave dispersion and left ventricular diastolic dysfunction in 
hypertensive and ischemic heart disease patients. Cardiovasc J, 8:13-18.

4. Tsai W., Lee K., Wu M., Chu C. 2013. Significant correlation of $\mathrm{P}$-wave parameters with left atrial. Am J Med Sci, 346:45-51.

5. Dilaveris P.E., Gialafos J.E., Fan K., Chiu C.S.W., Lee J.W.T., He G-W., et al. 2001. P-wave duration and dispersion analysis: methodological considerations response. Circulation, 103:e111-e111.

6. Nagueh S.F., Smiseth O.A., Appleton C.P., Byrd B.F., Dokainish H., Edvardsen T., et al. 2016. Recommendations for the evaluation of left ventricular diastolic function by echocardiography: An Update from the American Society of Echocardiography and the European Association of Cardiovascular Imaging. J Am Soc Echocardiogr, 29:277314.

7. Dahlan S. 2009. Penelitian Diagnostik: Dasar-dasar Teoretis dan Aplikasi dengan Program SPSS dan Stata. I. Jakarta: Salemba Medika; pp. 152.

8. Taha T.T., Sayed K., Saad M., Samir M. 2015. How accurate can electrocardiogram predict left ventricular diastolic dysfunction? The Egyp Heart J, 68: 117-123.

9. Dilaveris P., Batchvarov V., Gialafos J., Malik M. 1999. Comparison of different methods for manual $P$ wave duration measurement in 12-lead electrocardiograms. Pace, 22:15321538.

10. Srivastava P.M., Burrell L.M., Calafiore P. 2005. Lateral vs medial mitral annular tissue Doppler in the echocardiographic assessment of diastolic function and filling pressures: Which should we use? Eur $\mathrm{J}$ Echocardiogr, 6:97-106.

11. Gunduz H., Binak E., Arinc H., Akdemir R., Ozhan H., Tamer A., et al. 2005. The relationship between $\mathrm{P}$ wave dispersion and diastolic dysfunction. Texas Hear Inst J, 32:163-167.
12. Özer N., Aytemir K., Atalar E., Sade E., Aksöyek S., Övünç K., et al. 2000. P wave dispersion in hypertensive patients with paroxysmal atrial fibrillation. Pacing Clin Electrophysiol, 23:1859-1862.

13. Dilaveris P.E., Gialafos J.E. 2001. P-wave dispersion: a novel predictor of paroxysmal atrial fibrillation. Ann noninvasive Electrocardiol, 6:159-165.

14. Barutçu İ., Esen Ö., Kaya D., Onrat E., Melek M., Çelik A., et al. 2009. The relationship between aging and $\mathrm{P}$ wave dispersion. Koşuyolu Hear J, 12:5-9.

15. Dagli N., Karaca I., Yavuzkir M., Balin M., Arslan N. 2008. Are maximum P wave duration and $\mathrm{P}$ wave dispersion a marker of target organ damage in the hypertensive population? Clin Res Cardiol, 97:98-104.

16. Fogari R., Derosa G., Ferrari I., Corradi L., Zoppi A., Lazzari P., et al. 2008. Effect of valsartan and ramipril on atrial fibrillation recurrence and $\mathrm{P}$-wave dispersion in hypertensive patients with recurrent symptomatic lone atrial fibrillation. Am J Hypertens, 21:1034-1039.

17. Cuocolo A., Storto G., Izzo R., Luigi G., Damiano M., Bertocchi F., et al. 1999. Effects of valsartan on left ventricular diastolic function in patients with mild or moderate essential hypertension : comparison with enalapril. J Hypertens, 17:1759-1766.

18. Celik T., Iyisoy A., Kursaklioglu H., Yilmaz M.I., Kose S., Kilic S., et al. 2005. The comparative effects of telmisartan and ramipril on $\mathrm{P}$-wave dispersion in hypertensive patients: a randomized clinical study. Clin Cardiol, 28:298-302.

19. Korkmaz H., Onalan O., Akbulut M., Ozbay Y. 2009. Nebivolol and quinapril reduce $P$-wave duration and dispersion in hypertensive patients. Indian Pacing Electrophysiol J, 9:158-166. 
20. Hsieh Y.C., Hung C.Y., Li C.H., Liao Y.C., Huang J.L., Lin C.H., et al. 2016. Angiotensin-receptor blocker, angiotensinconverting enzyme inhibitor, and risks of atrial fibrillation. Medicine (Baltimore), 95:e3721.

21. Ehrlich J.R., Hohnloser S.H., Nattel S. 2006. Role of angiotensin system and effects of its inhibition in atrial fibrillation: clinical and experimental evidence. Eur Heart J, 27:512-518.
22. Camsari A., Pekdemir H., Akkus M.N., Yenihan S., Doven O., Cin V.G. 2003. Long-term effects of beta blocker therapy on P-wave duration and dispersion in congestive heart failure patients: a new effect? J Electrocardiol, 36:111-116.

23. Tatli E., Aktoz M., Barutcu A., Kurum T., Altun A. 2009. Effect of carvedilol on P-wave duration and $\mathrm{P}$-wave dispersion in patients with systolic heart failure. Trak Univ Tip Fak Derg, 26:226-231. 